\title{
Editorial
}

\section{Brand alignment across organisational boundaries}

In recent discussions with several experienced brand managers and senior marketing executives, nearly everyone expressed a persistent need for improving brand alignment in their organisations. Brand misalignment is a fast growing issue as companies move to quicker, more decentralised decision making with less marketing coordination across their divisions and business units. These professionals also commented on the continuing reductions in time, effort, and resources available for brand building, and the increasing pressures to broaden brand portfolios with ever more diverse products and services. Such trends pose especially difficult challenges for managing corporate and strategic brands that stretch across organisational boundaries.

The current business literature on strategic and operational alignment does not readily address many of their specific questions about brand management. After further study, Fax Strategy LLC developed a basic framework for exploring their issues and concerns. Building on earlier work by Interbrand, the framework identifies five principal areas for brand alignment: (1) leadership actions, (2) organisational structure, (3) people practices, (4) internal communications, and (5) performance measures and incentives. Our goal is to encourage further research on these specific topics for aligning brands.

\section{LEADERSHIP ACTIONS}

Several brand managers said their primary challenge was getting senior leadership in their companies to embrace the business implications of the brand and the brand positioning. Branding efforts were occasionally undermined by the remarks or actions of senior executives. When higherlevel management was not completely aligned with the brand, internal momentum usually faded as people within the organisation pulled the brand in different directions.

Because organisational alignment is a top-down imperative for corporate and strategic brands, a brand champion at the executive level is needed to promote and protect the brand internally. While other leadership approaches (as explained later) can also help to achieve brand alignment, the key is to maintain centralised control of core brands and manage them as strategic assets of the company.

\section{ORGANISATIONAL STRUCTURE}

Corporate executives seek to establish a workable balance between centralisation and decentralisation in running their businesses and managing core brands. However, companies with traditions of autonomous business units, independent country managers, or decentralised marketing functions find it challenging to maintain brand consistency across the organisation.

Rationalisations for brand misalignment abound. Some companies take a very relaxed approach to brand alignment for new acquisitions and start-ups because of pressing business development and integration issues. Other 
companies are reluctant to deal with legacy brands that no longer fit existing business directions or brand architectures. In entrepreneurial companies, product groups that do not buy into the overall brand positioning sometimes promote a different brand identity to appeal to a specialised market niche.

In one case, a major consumer packaged goods company had no less than 16 independent product groups each promoting and advertising separate benefit positions for the same 100-year old brand. As internal competition reportedly escalated, larger product groups tried to outspend other groups in the same company to ensure their benefits were the ones consumers most closely associated with the brand.

Changing such organisational behaviour requires a strong, shared interest and discipline in safeguarding the brand. To accomplish these objectives, many leading companies have established global brand councils consisting of stakeholders from all relevant divisions, business units, and geographies. These centralised committees are typically led by a senior executive and meet regularly to set brand strategy, make policy, review plans, and resolve disputes. Brand councils provide a central forum to exchange differing perspectives and discuss special needs in managing the brand across organisational boundaries. Stakeholders are better able to evaluate the collective impact of individual initiatives and assess the value created in aligning their businesses with the brand.

\section{PEOPLE PRACTICES}

Several popular books and articles describe how 'internal branding' programmes help organisations build strong brand cultures and encourage employees to 'live the brand'. Our discussions with experienced brand managers and senior marketing executives, however, focused on more basic issues.

For example, senior executives voiced frustrations about the relative inexperience and rapid turnover of brand managers and members of their brand teams; they also raised concerns about the very limited brand training of many customer-facing employees and business partners.

Meanwhile, brand managers pointed out the overall brand strategy was not always well communicated from above - often directing employees to behave in contradictory ways. They also commented how extraordinarily slow and cumbersome the upper-level approval process was for routine branding requests. In responding to dynamic market conditions, many brand managers agreed, 'It's better to ask forgiveness than to ask for permission', as they moved ahead on their own marketing initiatives.

If these perspectives are valid, then organisations will likely face chronic brand misalignment. Rather than trying to change behaviours or the people involved, some organisations establish corporate-level brand expertise centres. The experienced brand experts and business coaches who staff these centres are empowered to move quickly across the entire organisation to engage brand teams, help evaluate brand investments, coordinate multidivisional product launches, mediate branding disputes, and share internal best practices and experiences. Brand expertise centres can also oversee brand education programmes 
for middle and senior managers, and run brand training exercises for company employees, business partners, major suppliers, and even key customers.

Some innovative organisations have migrated many functions of their expertise centres to brand hubs on company intranet sites. These network-based brand hubs provide online assistance: to develop branding materials that conform to established brand guidelines; obtain immediate decisions on branding requests; deliver real-time information about various brand activities in the organisation; and offer online brand programmes and interactive training exercises in different languages to accommodate employees and partners throughout the world.

\section{INTERNAL COMMUNICATIONS}

Steve Overman of Jack Morton Worldwide advises client companies to 'brand from the inside out'. He observes that well-aligned brand organisations share three common traits in their internal communications: clarity, coherence, and authenticity. ${ }^{1}$

- Clarity: 'Everyone gets it. The brand promise and attributes are clearly articulated and understood by employees and partners'.

- Coherence: 'It's all connected. The brand promise and attributes are embedded consistently throughout the organisation and across every touch point ....

- Authenticity: 'External messaging is a truthful reflection of internal reality; employees and customers perceive that the brand delivers on what it promises'.
Despite widespread recognition of these traits, most brand managers and marketing executives with whom we spoke noted repeated obstacles in aligning so many internal communications in their organisations. While there is no single approach to recommend here, the general agreement is that misalignment in internal communications diminishes significantly with the active involvement of brand champions, councils, or expertise centres.

\section{PERFORMANCE MEASURES AND INCENTIVES}

A less obvious source for brand misalignment lies in performance measures and organisational incentive systems. For example, middle-level management incentives are often designed to reward individual business success over the whole company's success. Such performance incentives are not well aligned with managing brands that span organisational boundaries. One business unit may introduce a brand extension that lifts sales in its particular market, but dilutes the overall brand franchise and causes unintentional problems for other business units. If other units were also to act in their own self-interest, the core brand could be weakened considerably.

Many organisational incentive systems unwittingly create a social dilemma, where (i) each individual's cooperation in using a common good (ie upholding the brand strategy) contributes a small amount to everyone's welfare, but (ii) each individual obtains a much greater payoff from not cooperating (ie modifying the brand to serve one's 
special interests). The equilibrium behaviour in such social dilemmas is called the 'tragedy of the commons', because people acting in their own self-interest choose not to cooperate and thereby deplete the common good. The altruistic few who choose to cooperate further increase the payoffs of those who defect and thereby support uncooperative behaviour within the organisation.

Achieving brand alignment requires making certain organisational changes to resolve the social dilemma embedded in many business incentive systems. Research studies on the evolution of cooperation suggest four approaches: (1) imposing a central authority, (2) developing binding commitments, (3) removing uncooperative individuals, or (4) restructuring performance incentives. First, a proactive brand champion at the executive level can establish norms for managers to act collaboratively in using a common brand. Secondly, global brand councils can work together to create and enforce policies that commit everyone to a common brand strategy. Thirdly, if some brand managers cannot 'play nicely with others in the sand box', then the organisation may ultimately need to replace them. Finally, restructuring performance incentives to promote alignment requires having dependable brand measures available for evaluating and rewarding employees.

In managing their core brands, many organisations already track multiple measures of effectiveness, such as brand awareness, reputation, associations, expectations, consideration, preference, quality, satisfaction, loyalty, advocacy, and others. Such metrics can be essential tools for brand decision- making, but they do not necessarily avoid the tragedy of the commons in managing corporate or strategic brands across multiple business units.

What is often missing is a brand metric for explicitly gauging cooperation and alignment. Pioneering companies have perfected brand portfolio metrics that not only cover the direct effects of a given branding activity but also capture the indirect consequences on other elements in the brand portfolio and across the company. In these organisations, branding proposals must include a manager's forecast of the likely impact on the brand portfolio metric as a way of balancing shared interests and protecting the brand. With continued refinement, these brand portfolio metrics are integrated with other business performance measures to more appropriately evaluate and reward brand managers and other employees in the organisation.

\section{RECOMMENDATIONS}

Brand misalignment is a growing issue for many organisations. While there is still much work to be done, we suggest five proven tactics to align core brands across organisational boundaries:

(1) Enlist the leadership of a brand champion to help promote and protect the brand internally.

(2) Form a global brand council to provide a central forum for balancing the interests of multiple stakeholders in creating brand strategy and policies.

(3) Develop brand expertise centres and network-based hubs to disseminate brand knowledge and ex- 
perience quickly and consistently throughout the organisation.

(4) Manage internal brand communications to ensure their clarity, coherence, and authenticity.

(5) Restructure organisational incentives by incorporating brand portfolio metrics and other performance measures that explicitly reward successful collaboration and brand alignment.

These brand alignment recommendations can help put organisations on track to manage their core brands profitably for the long term.

\section{Peter H. Farquhar Editorial Board}

Copyright (C) Fox Strategy LLC, 2005. All rights reserved.

\section{Reference}

(1) Steve Overman did not label this trait in 'The seven heuristics of brand aligned organizations,' $360^{\circ}$ Newsletter (September $30,2003)$, so we coined the term authenticity here. 